\title{
Estimation of the density of the Near Threatened jaguar Panthera onca in Sonora, Mexico, using camera trapping and an open population model
}

\author{
Carmina E. Gutiérrez-González, Miguel Á. Gómez-Ramírez and \\ Carlos A. López-González
}

\begin{abstract}
Our objective in this study was to determine the density of the jaguar Panthera onca from camera-trap data, using an open population model, in a private protected natural area, the Northern Jaguar Reserve, and 10 adjoining cattle ranches in the state of Sonora, Mexico. The region is considered a long-term jaguar conservation unit. As well as being the most northerly recorded reproductive population of the jaguar, the arid habitat of this region is atypical for the species. During 16 months of sampling we identified 10 individual jaguars and the data met the three main assumptions of open population models. The estimated mean density was $1.05 \pm \mathrm{SE} 0.4$ individuals per $100 \mathrm{~km}^{2}$, with a constant survival probability of 0.94 and capture probability of 0.23 . This estimate of density is lower than reported in studies of the jaguar from more southerly locations in Mexico, Belize, Costa Rica, Bolivia and Brazil but cannot be attributed to a single factor even though in general there is an apparent relationship between jaguar density and precipitation. The main objectives of the management of the Northern Jaguar Reserve are to reduce the impact of cattle and restore jaguar habitat, with strategies focused on water retention, removal of invasive grass, reforestation and environmental education. Livestock have been gradually excluded since 2003 and, combined with the protection provided under the agreements with the surrounding ranches, the area is now a suitable place for long-term studies of the jaguar.
\end{abstract}

Keywords Capture probability, density, Felidae, jaguar, Mexico, open population, Panthera onca, Sonora

\section{Introduction}

The jaguar Panthera onca is categorized as Near

Carmina E. Gutiérrez-GonZález (Corresponding author) and Miguel Á. GÓmeZ-RAmírez Naturalia Comité para la Conservación de Especies Silvestres A. C. El Cajón 9. Col. Santa Fe. C.P. 83249. Hermosillo, Sonora, México. E-mail reservajaguar@gmail.com

Carlos A. LópeZ-GonzÁlez Laboratorio de Zoología, Facultad de Ciencias Naturales, Universidad Autónoma de Querétaro, Santiago de Querétaro, Querétaro, México

Received 28 October 2010. Revision requested 19 January 2011

Accepted 21 February 2011. is typically associated with tropical forests, ecosystems characterized by their high primary productivity (Seymour, 1989; Crawshaw \& Quigley, 1991). This large felid has a wide distribution, however, indicating a high plasticity in its tolerance of environmental variation that permits it to exist in marginal habitats. This is the case of the northernmost reproductive population of jaguars, in Mexico (Brown \& López González, 2001), where the species' habitat is dominated by arid conditions (Brown, 1994) but where non-native prey (i.e. livestock) are widely available. This northern population of the jaguar is of particular interest because it may be a unique gene pool adapted to extreme environmental conditions. Nevertheless, despite its conservation importance, this population has been little studied (e.g. Rosas-Rosas et al., 2008). The region is considered a long-term jaguar conservation unit (Sanderson et al., 2002; Rabinowitz \& Zeller, 2010).

The most commonly used method to estimate abundance and density of jaguars is by camera trapping, which facilitates individual identification (Wallace et al., 2003; Silver et al., 2004). Most such studies span 2-3 months and consider populations to be closed (Wallace et al., 2003; Silver et al., 2004; Cavalcanti \& Gese, 2009); i.e. it is assumed there are no births or deaths during the sampling period. Considering that populations can suffer losses or additions within short periods of time it is important to expand research methods so that temporal variations can be examined but such changes are not considered in closed population analysis (Mohd Azlan \& Sharma, 2003; Heilbrun et al., 2006). Open population models are an alternative and make the following assumptions: (1) each animal in the population has the same probability of being captured sometime during the sampling period provided it is alive during the sampling, (2) each animal in the population has the same probability of survival from time $i$ to time $i+1$, and (3) individual markings (physical characteristics) are not missing and individuals cannot be misidentified (Pollock et al., 1990; Morrison et al., 2008).

Our objective in this study was to determine jaguar density from camera-trap data, using an open population model. Because of the arid conditions of the study site we assumed that the estimated densities of jaguars would be lower than densities reported for jaguar populations in more productive areas. 


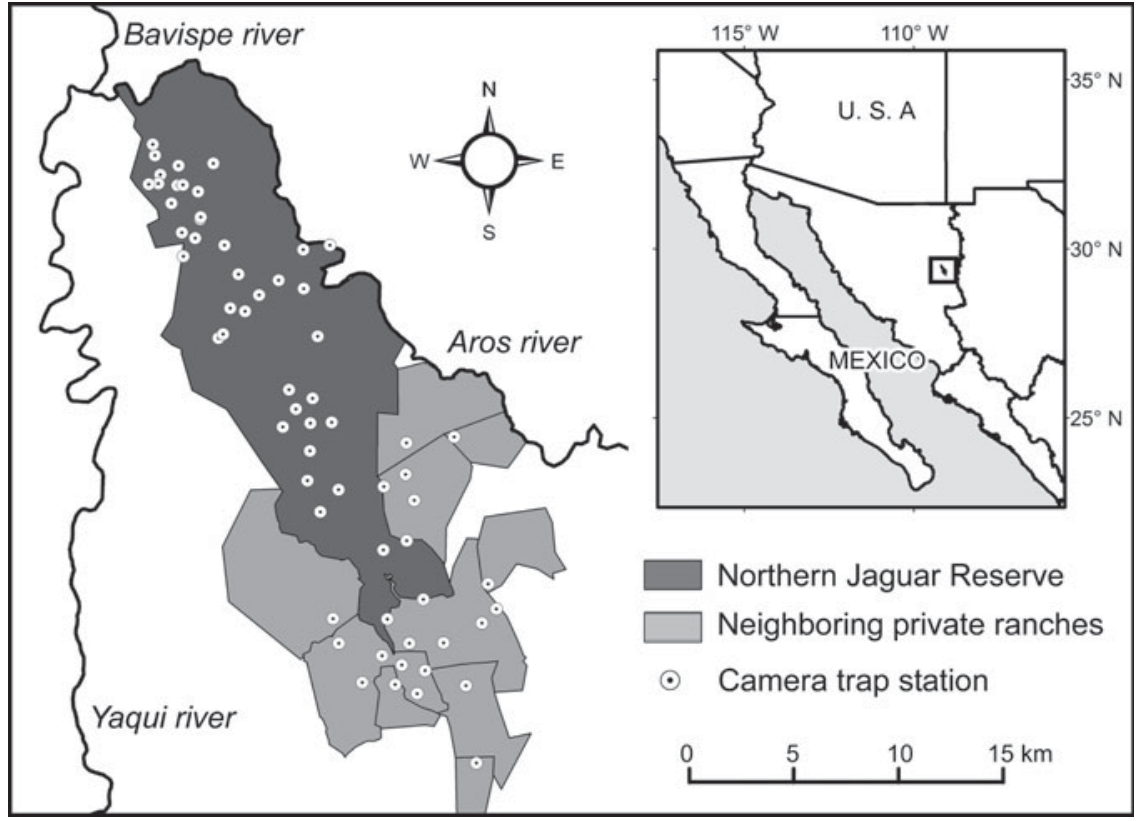

FIG. 1 Locations of camera traps in the Northern Jaguar Reserve and neighbouring ranches. The rectangle on the inset shows the location of the main map in Sonora, north-west Mexico.

\section{Study area}

The study was carried out in the east-central region of the state of Sonora, Mexico, in a private protected natural area, the Northern Jaguar Reserve, and 10 adjoining cattle ranches (Fig. 1). The study site covers an area of c. $330 \mathrm{~km}^{2}$ and, because of its isolated location, is an area without high human impacts. Vegetation is a heterogeneous mosaic of mostly xerophilous and Sinaloan thorn scrub, tropical deciduous forest, and riparian vegetation with palms, holm oaks and natural grasslands. Dominant plant species are Lysiloma watsonii, Prosopis velutina, Vachelia campechana (= Acacia cochliacantha), Jatropha cordata, Sabal uresana, Brahea brandegeei, Senegalia occidentalis (= Acacia occidentalis), Havardia mexicana, Salix bonplandiana, Baccharis salicifolia and Ambrosia ambrosioides. This vegetation is interspersed within large areas of non-native grassland (dominated by buffel grass Penisetum ciliare; Brown, 1994). Mean annual precipitation is $<400 \mathrm{~mm}$, distributed throughout the year and with winter rains accounting for $18 \%$ of the annual total. Mean annual temperature varies from $16^{\circ} \mathrm{C}$ in winter to $30^{\circ} \mathrm{C}$ in summer, with extreme temperatures from -7 to $43^{\circ} \mathrm{C}$ (Brown, 1994; García \& CONABIO, 1998). The adjoining cattle ranches signed an agreement in 2006 to not hunt wildlife and we therefore consider the Reserve and cattle ranches as a single area.

\section{Methods}

\section{Fieldwork}

The number of camera traps used varied from 25 to 111 . We used three camera trap models: Camtrakker $35 \mathrm{~mm}$
(Camtrakker, Watkinsville, USA), Wildview (Wildview, Grand Praire, USA) and Cuddeback (Non Typical Inc., Green Bay, USA). Most camera traps were placed in pairs, to facilitate identification of individual jaguars using photographs of both flanks (Karanth \& Nichols, 2000), along game trails, streams and narrow canyons. To avoid bias in individual detection no attractant was used. Camera traps were placed according to the web-trap design proposed by Anderson et al. (1983), with modifications as described by Gutiérrez-González (2008). We carried out monthly sampling from February 2009 to May 2010. Each month was considered a sampling session, with 16 sessions in total.

\section{Data analysis}

Each photograph of a jaguar was associated with an individual. Those photographs in which the individual could not be identified were discarded from the analysis. A capture history was developed using the data for each sampling period, considering each individual photograph as a capture and a new photograph of the same individual as a recapture (Di Bitetti et al., 2006). Capture history was analysed with CloseTest v. 3 (Stanley \& Richards, 1999) to determine if the population was open or closed. CloseTest compares assumptions between open population models (losses and recruitments in the population) against closed population models (no additions or losses to the population). The capture record was then analysed according to the Jolly-Seber model using JOLLY (Pollock et al., 1990), which can estimate parameters related to abundance such as population growth, recruitment and abundance. Density in each sampling period and mean density over the 


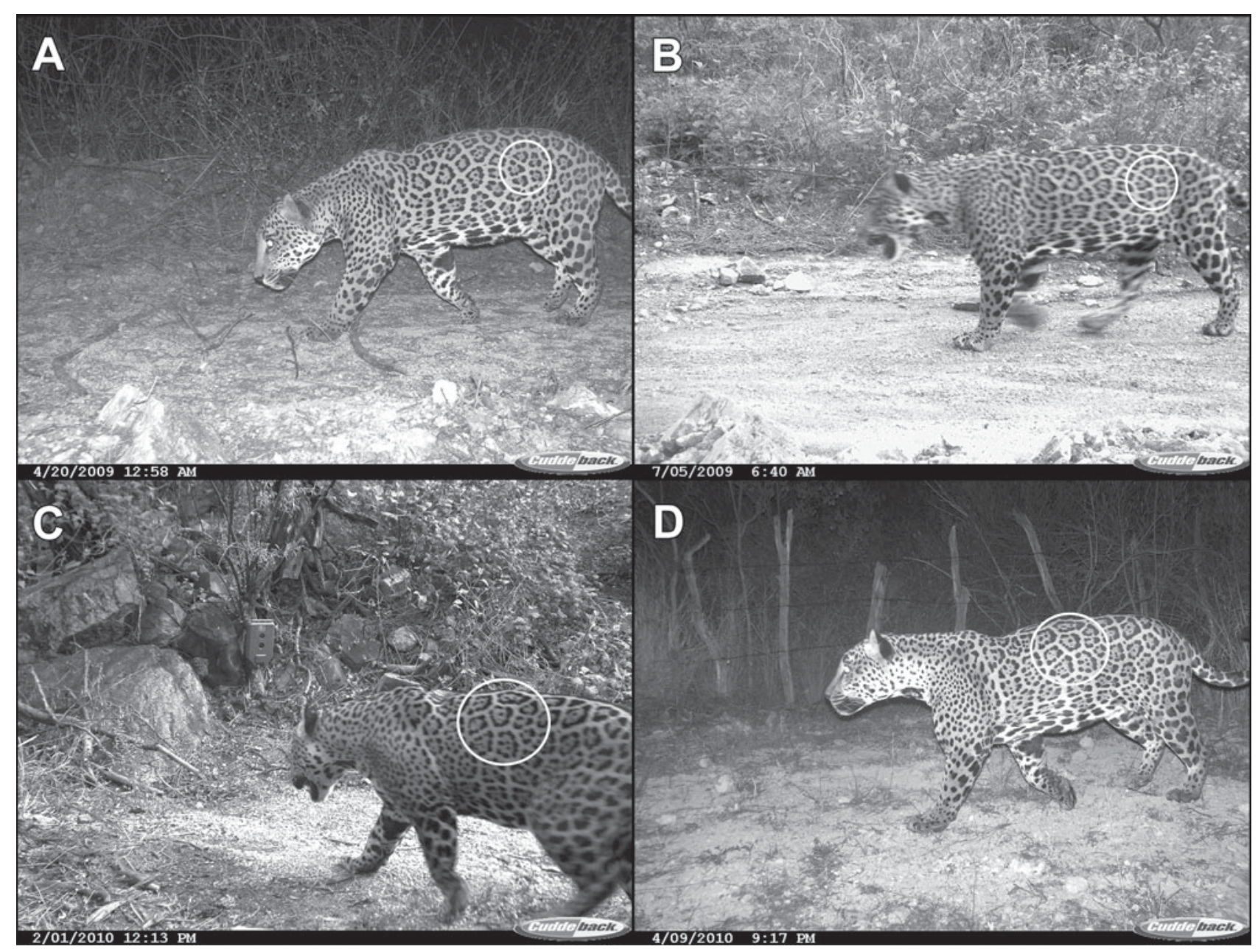

Plate 1 Examples of photo identification of individual jaguars Panthera onca using camera-trap photographs. Images A and B are of individual JM-11 and images C and D of individual JNI-10 (Table 1).

whole sampling period was calculated from estimates of abundance obtained from JOLLY divided by the sampled area (Karanth et al., 2004; Silver, 2004). JOLLY provides a series of $\chi^{2}$ comparisons between capture and survival probabilities and determines the best estimators for these parameters.

The sampled area was calculated taking as a basis the male jaguar home range with the highest number of records since 2006 to date (authors, unpubl. data), using the estimate of the mean maximum distance moved (MMDM; Silver, 2004). MMDM was estimated as the mean of the sum of all distances between two capture sites (camera locations) (Karanth \& Nichols, 1998). We used the mean obtained as a radius to calculate a circular buffer around each camera location. All buffer areas for each camera location were summed for each sampling period to give an estimate of the sampling area by period (Karanth et al., 2004; Silver, 2004).

To test if jaguar density in general is related to productivity we used a linear regression model with jaguar density from this and 20 other studies (in Mexico,
Belize, Costa Rica, Brazil and Bolivia) as the dependent variable and annual precipitation as the independent variable. We assumed that productivity is proportional to precipitation.

\section{Results}

The mean area covered by camera traps plus the buffer area was $684.6 \pm \mathrm{SE} 162.3 \mathrm{~km}^{2}$. Variations in the size of the sampling area were caused by the loss or acquisition of cameras. During the 16 months of sampling a total of 7,718 trap nights were accumulated, with 63 photographs of jaguars, from which 10 individuals were identified (four males, three females and three individuals for which sex could not be determined; Plate 1, Table 1).

All assumptions of the open population model appeared to be met. According to CloseTest the capture history fits the open population model $\left(\chi^{2}=23.9, \mathrm{df}=11, \mathrm{P}=0.013\right)$. There were no additions of individuals $(P=1)$ but there were losses $(\mathrm{P}=0.013)$. The data did not fit a linear model 
TABLE 1 Capture history of the 10 jaguars Panthera onca identified in the Northern Jaguar Reserve and adjoining ranches in Sonora, México (Fig. 1), in 16 monthly sampling periods from February 2009 to May 2010. An entry of 1 indicates capture of the individual.

\begin{tabular}{|c|c|c|c|c|c|c|c|c|c|c|c|c|c|c|c|c|}
\hline \multirow[b]{2}{*}{ Individual } & \multicolumn{16}{|c|}{ Sampling period } \\
\hline & 1 & 2 & 3 & 4 & 5 & 6 & 7 & 8 & 9 & 10 & 11 & 12 & 13 & 14 & 15 & 16 \\
\hline $\mathrm{JH}-2$ & 0 & 0 & 0 & 0 & 1 & 0 & 0 & 0 & 0 & 0 & 0 & 0 & 0 & 0 & 0 & 0 \\
\hline JH-9 & 0 & 1 & 0 & 0 & 0 & 0 & 0 & 0 & 0 & 0 & 0 & 0 & 0 & 0 & 0 & 0 \\
\hline JH-11 & 0 & 0 & 0 & 1 & 0 & 1 & 1 & 0 & 0 & 0 & 1 & 0 & 0 & 0 & 0 & 0 \\
\hline JM-1 & 1 & 0 & 0 & 0 & 0 & 0 & 0 & 0 & 0 & 0 & 1 & 0 & 0 & 0 & 1 & 1 \\
\hline JM-11 & 1 & 1 & 1 & 1 & 0 & 1 & 0 & 0 & 0 & 0 & 1 & 1 & 0 & 0 & 0 & 0 \\
\hline JM-12 & 0 & 0 & 0 & 0 & 0 & 0 & 0 & 0 & 0 & 0 & 1 & 0 & 0 & 1 & 1 & 1 \\
\hline JNI-5 & 0 & 0 & 1 & 0 & 0 & 0 & 0 & 0 & 0 & 0 & 0 & 0 & 0 & 0 & 0 & 0 \\
\hline JNI-9 & 1 & 0 & 0 & 0 & 0 & 0 & 0 & 0 & 0 & 0 & 0 & 1 & 0 & 0 & 0 & 0 \\
\hline JNI-10 & 0 & 0 & 0 & 0 & 0 & 0 & 0 & 0 & 0 & 0 & 0 & 0 & 1 & 0 & 1 & 0 \\
\hline JNI-11 & 0 & 0 & 0 & 0 & 0 & 0 & 0 & 0 & 0 & 0 & 0 & 0 & 0 & 0 & 0 & 1 \\
\hline
\end{tabular}

TABLE 2 Estimated effective sampling area calculated using the mean maximum distance moved (see text for details), and mean density \pm SE of the jaguar population in the 16 monthly sampling periods.

\begin{tabular}{lll}
\hline $\begin{array}{l}\text { Sampling } \\
\text { Period }\end{array}$ & $\begin{array}{l}\text { Effective } \\
\text { sampling } \\
\text { area }\left(\mathrm{km}^{2}\right)\end{array}$ & $\begin{array}{l}\text { Density } \pm \text { SE } \\
\left(100 \mathrm{~km}^{-2}\right)\end{array}$ \\
\hline 2009 & & \\
Feb. & 907.6 & $1.01 \pm 0.51$ \\
Mar. & 760.9 & $0.98 \pm 0.49$ \\
Apr. & 779.7 & $0.97 \pm 0.49$ \\
May & 792.6 & $1.77 \pm 0.77$ \\
June & 505.3 & $0.96 \pm 0.17$ \\
July & 498.0 & $1.06 \pm 0.19$ \\
Aug. & 456.3 & $1.06 \pm 0.20$ \\
Sep. & 463.2 & $0.95 \pm 0.20$ \\
Oct. & 531.8 & $0.98 \pm 0.23$ \\
Nov. & 531.8 & $1.23 \pm 0.54$ \\
Dec. & 778.4 & \\
2010 & & $0.72 \pm 0.20$ \\
Jan. & 802.3 & $0.91 \pm 0.50$ \\
Feb. & 812.7 & $0.67 \pm 0.26$ \\
Mar. & 831.1 & $0.90 \pm 0.39$ \\
Apr. & 817.4 & $1.52 \pm 0.79$ \\
May & 823.3 &
\end{tabular}

$\left(r^{2}=0.05, \mathrm{P}=0.38\right)$, supporting the rejection of the use of a closed population model (Heilbrun et al., 2006).

The best model explaining the capture record included a constant survival rate $(\varphi=0.94)$ and a constant capture probability $(\mathrm{P}=0.23)$ throughout the sampling period $(\mathrm{P}=0.82)$. Mean jaguar density was estimated to be $1.05 \pm \mathrm{SE} 0.4$ per $100 \mathrm{~km}^{2}$. Variation in estimates per sampling period is shown in Table 2 .

The linear regression confirms that jaguar density is positively related to precipitation (Fig. 2) and therefore presumably to productivity. In general, higher densities of jaguars have been reported from areas with higher precipitation.

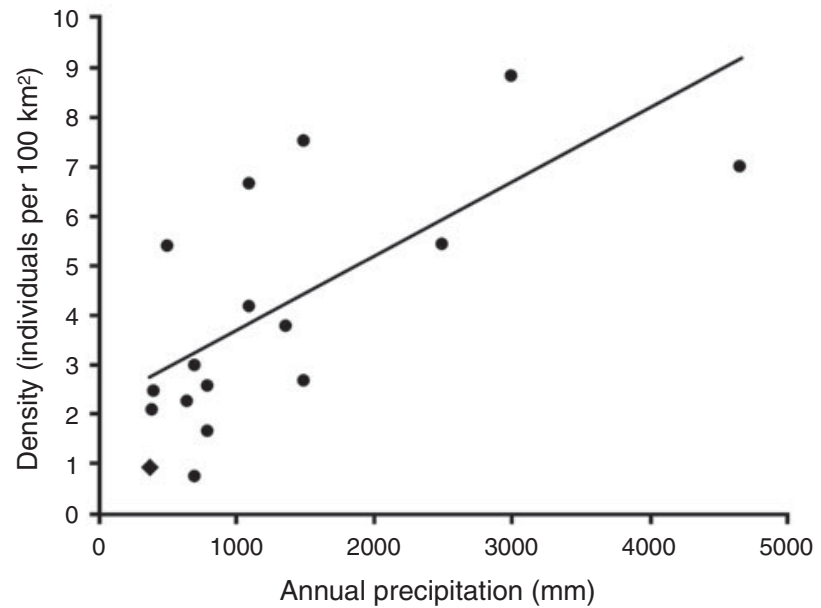

FIG. 2 Linear regression model $\left(\mathrm{r}^{2}=0.40, \mathrm{P}=0.001\right)$ showing the relationship between jaguar Panthera onca density, using published data $(\bullet)$ and data from this study ( $\bullet$ ) (Table 3 ), and total annual precipitation.

\section{Discussion}

As far as we are aware this is the first study to calculate densities of an open jaguar population using data from camera trapping. The only other long-term jaguar study that considered an open population focused on the social interaction between jaguars over 10 years of monitoring, and used radio telemetry (Cavalcanti \& Gese, 2009). Camera trapping has been widely used for calculations of density in closed populations of various species. We consider that its application can be extended for prolonged periods, especially for those species that require long-term management and extensive monitoring strategies for their conservation, such as jaguars.

Our survey met the three main assumptions of open population models (Pollock et al., 1990; Morrison et al., 2008): (1) We used an homogenous method for camera location that assumes all animals have the same capture probability and we did not use any attractants 
TABLE 3 Jaguar density estimated in 21 studies in five countries, with annual total precipitation of the study sites, arranged in order of increasing density.

\begin{tabular}{lllll}
\hline Study area & Country & $\begin{array}{l}\text { Density } \pm \text { SE } \\
\left(100 \mathrm{~km}^{-2}\right)\end{array}$ & $\begin{array}{l}\text { Annual precipitation } \\
(\mathrm{mm})\end{array}$ & Reference \\
\hline Queretaro & Mexico & 0.75 & 700 & Coronel-Arellano et al. (2008) \\
Sonora & Mexico & $1.05 \pm 0.40$ & 377 & This study \\
Tuichi Valley & Bolivia & $1.68 \pm 0.78$ & 800 & Wallace et al. (2003) \\
Guanacos & Bolivia & $2.05 \pm 0.21$ & 400 & Noss et al. (2004) \\
Ravelo & Bolivia & $2.27 \pm 0.89$ & 650 & Noss et al. (2004) \\
Parque Nacional Kaa Iya & Bolivia & $2.46 \pm 0.60$ & 400 & Cuellar (2004) \\
Tucavaca & Bolivia & $2.57 \pm 0.77$ & 800 & Noss et al. (2004) \\
Parque Serra da Capivara & Brazil & $2.67 \pm 1.06$ & 1,500 & Silveira et al. (2009) \\
Madidi & Bolivia & $2.84 \pm 1.78$ & 700 & Silver et al. (2004) \\
Parque Nacional Kaa Iya & Bolivia & 3.0 & 700 & Peña et al. (2004) \\
Yucatan & Mexico & $3.76 \pm 2.21$ & 1,365 & Faller et al. (2007) \\
Tucavaca & Bolivia & $3.93 \pm 1.30$ & 800 & Silver et al. (2004) \\
Campeche & Mexico & 4.16 & 1,100 & Aranda (1998) \\
Cerro Colorado & Bolivia & $5.11 \pm 2.10$ & 500 & Silver et al. (2004) \\
Cerro Colorado & Bolivia & $5.38 \pm 1.79$ & 500 & Noss et al. (2004) \\
Talamanca & Costa Rica & $5.42 \pm 2.30$ & 2,500 & González-Maya (2007) \\
Campeche & Mexico & 6.66 & Ceballos et al. (2005) \\
Corcovado National Park & Costa Rica & $6.98 \pm 2.36$ & 4,656 & Salom-Pérez et al. (2007) \\
Chiquibul & Belize & $7.48 \pm 2.74$ & 1,500 & Silver et al. (2004) \\
Chiquibul & Belize & $7.48 \pm 2.74$ & 1,500 & Noss et al. (2004) \\
Cockscomb & Belize & $8.80 \pm 2.25$ & 3,000 & Silver et al. (2004) \\
\hline
\end{tabular}

(Yasuda, 2004). (2) Statistical results for the best model (constant capture and survival probabilities) showed that all jaguars had a constant survival probability throughout all 16 survey sessions. (3) All jaguars could be identified in photographs by their unique marks. We therefore suggest that open population models can be a reliable way to analyse data from $>6$ months of camera-trap sampling (O'Brien, 2011). Most closed population analyses use sampling blocks of $2-3$ months to fit the assumption that the population is closed but this kind of blocking can be arbitrary. Our alternative analysis includes all sampling periods without arbitrary blocking.

In short-term studies using closed populations models it is possible for individuals to be captured only once, leading to biased estimations of abundance or closure testing. In our study four individuals were captured only once; two of them are females that we captured later as part of long-term monitoring (Gutiérrez-González \& López-González, 2011). The other two were captured in the outer limits of the study area and therefore may be transients at our study site. The use of open population models allows researchers to include individuals captured only once without bias in model selection and without violating the model's assumptions.

In all studies of density it is important to consider each record individually to understand capture history and correctly determine whether to use open or closed population models (O'Brien, 2011). When most of the captures are within the limits of the study area we suggest the use of spatial mark-recapture models, as described by Partanen \& Penttinen (2007).

As there is a lack of previous camera-trap studies of jaguars using open population models, comparison of our results with other studies is tentative. The density of jaguars estimated in our study is lower than that reported elsewhere (Table 3), even for studies in Mexico. However, we found a positive relationship between jaguar density and precipitation in general (Fig. 2), suggesting an effect of productivity on carrying capacity.

The density of jaguars at our study site was relatively unchanged between months. However, the estimated densities in June 2009 and May 2010 were almost two-fold higher and coincided with the driest months of the study period. As the Northern Jaguar Reserve and some of the neighbouring ranches provide an area with permanent water it is possible that jaguars concentrated in this area, where natural prey is greater. In the months with higher precipitation water availability may not be a limiting factor for jaguar dispersion. Despite the different management regimes of the reserve and cattle ranches the constant survival probabilities confirm that management on cattle ranches, with the wildlife protection agreement, and the exclusion of cattle from the Reserve had a positive impact on jaguars in the whole study area. However, although the agreements signed with neighbouring landowners have resulted in an increase in records of jaguars and their prey it is important to continue the long-term monitoring. 
The low density of jaguars in our study cannot be attributed to a single factor even though there is an apparent relationship between jaguar density and precipitation. Livestock rearing is the most common farming activity in northern Mexico and we believe that the historical effects of livestock on vegetation structure and water availability may have altered the availability of forage and the abundance of jaguar prey. Nevertheless our analysis has demonstrated an overall high probability of jaguar survival that, together with 10 years of jaguar monitoring (Gutiérrez-González \& LópezGonzález, 2011), suggests jaguars are able to survive in this arid region.

The site of this research is a priority area for jaguar conservation and study (Sanderson et al., 2002). The main objectives of the management of the Northern Jaguar Reserve are to reduce the impact of cattle and restore jaguar habitat, with strategies focused on water retention, removal of invasive grass, reforestation and environmental education. Livestock have been gradually excluded since 2003 and, combined with the protection provided under the agreements with the surrounding ranches, the area is now a suitable place for long-term studies of the jaguar. It is important to continue research in this area to determine if the present management strategy can continue to maintain, and increase, jaguar populations in these arid lands of North America.

\section{Acknowledgements}

We would like to thank Naturalia A.C., Northern Jaguar Project Inc., Universidad Autónoma de Querétaro, The Denver Zoo, Defenders of Wildlife, Disney Worldwide Conservation Fund, Robert \& Michelle Friend Foundation, Jeniam Foundation, J.M. Kaplan Fund, J.W. Kieckhefer Foundation, Wendy P. McCaw Foundation, Margaret T. Morris Foundation, Neotropical Migratory Bird Conservation Act, David \& Lucile Packard Foundation, Patagonia, Shared Earth Foundation, Wilburforce Foundation and all the organizations and people who granted funds for this project. We are grateful to all the researchers and other people who over 10 years helped us monitor jaguars in the Northern Jaguar Reserve. We thank two anonymous reviewers for their comments and Dr Robert W. Jones for reviewing and editing the English.

\section{References}

Anderson, D., Burnham, K. \& White, G. (1983) Density estimation of small-mammal populations using a trapping web and distance sampling methods. Ecology, 64, 674-680.

Aranda, M. (1998) Densidad y estructura de una población de jaguar (Panthera onca) en la Reserva de la Biósfera Calakmul, Campeche, México. Acta Zoológica Mexicana, 75, 199-201.
Brown, D.E. (1994) Biotic Communities: Southwestern United States and Northwestern Mexico. University of Utah Press, Salt Lake City, USA.

Brown, D.E. \& López GonzÁlez, C.A. (2001) Borderland Jaguars: Tigres de la Frontera. University of Utah Press, Salt Lake City, USA.

Cavalcanti, S. \& Gese, E.M. (2009) Spatial ecology and social interactions of jaguars (Panthera onca) in the southern Pantanal, Brazil. Journal of Mammalogy, 90, 935-945.

Ceballos, G., Chávez, C., Zarza, H. \& Manterola, C. (2005) Ecología y conservación del jaguar en la región de Calakmul. Biodiversitas, 62, 1-7.

Coronel-Arellano, H., López-González, C.A., LorenzanaPiña, G.P. \& Ortega Urrieta, A.M. (2008) El jaguar (Panthera onca) en Querétaro. Extensión Nuevos Tiempos, 2, 29-34.

Crawshaw, P.G. \& Quigley, H.B. (1991) Jaguar spacing, activity and habitat use in a seasonally flooded environment in Brazil. Journal of Zoology, 223, 357-370.

Cuellar, E. (2004) Primer muestreo de jaguares Panthera onca en pampa, zona Guanacos, Parque Nacional Kaa-Iya del Gran Chaco. MEMORIAS: Manejo de Fauna silvestre en Amazonia y Latinoamérica, 4, 158-165.

Di Bitetti, M., Paviolo, A. \& De Angelo, C. (2006) Density, habitat use and activity patterns of ocelots (Leopardus pardalis) in the Atlantic Forests of Misiones, Argentina. Journal of Zoology, 264, 1-11.

Faller, J.C., Chávez, C., Jonson, S. \& Ceballos, G. (2007) Densidad y tamaño de la población del jaguar en el noroeste de la Península de Yucatán. In Conservación y manejo del jaguar en México: estudios de caso y perspectivas (eds G. Ceballos, C. Chávez, R. List \& H. Zarza), pp. 111-122. CONABIO-UNAM-Alianza WWF Telcel., México D.F., México.

García, E. \& CONABio (Comisión Nacional para el USO Y Conocimiento de la biodiversidad) (1998) "Climas" (clasificación de Koppen, modificado por García). Escala $1: 1,000,000$. México.

GonzÁlez-Maya, J.F. (2007) Densidad, uso de hábitat y presas del jaguar (Panthera onca) y el conflicto con humanos en la región de Talamanca, Costa Rica. MSc thesis, Centro Agronómico Tropical de Investigación y Enseñanza, Turrialba, Costa Rica.

GutiérReZ-GonZÁlez, C.E. (2008) La comunidad de carnívoros en la zona semiárida de Cadereyta, Querétaro. MSc thesis, Instituto de Ecología, Xalapa, Veracruz, México.

Gutiérrez-GonzÁlez, C.E. \& López-González, C.A. (2011) Report of the Results of Data Analysis from the Biological Monitoring of the Northern Jaguar Reserve: Period 1999-2009. Report for Northern Jaguar Project, December 2009. Naturalia A.C/Northern Jaguar Project, Hermosillo, Sonora, Mexico.

Heilbrun, R., Silvy, N., Peterson, M. \& Tewes, M. (2006) Estimating bobcat abundance using automatically triggered cameras. Wildlife Society Bulletin, 34, 69-73.

IUCN (2011) IUCN Red List of Threatened Species v. 2011.1. Http:// www.iucnredlist.org [accessed 11 October 2011].

Karanth, K.U., Chundawat, R.S., Nichols, J.D. \& Kumar, N.S. (2004) Estimation of tiger densities in the tropical dry forests of Panna, Central India, using photographic capture-recapture sampling. Animal Conservation, 7, 285-290.

Karanth, K.U. \& Nichols, J. (1998) Estimation of tiger densities in India using photographic captures and recaptures. Ecology, 79, 2852-2862.

Karanth, K.U. \& Nichols, J. (2000) Camera Trapping Big Cats: Some Questions that Should Be Asked Frequently. Wildlife Conservation Society, International Programs, New York, USA, and US Geological Survey-Patuxent, Wildlife Research Center, Maryland, USA. 
Mohd Azlan, J. \& Sharma, D. (2003) Camera tapping the Indochinese tiger, Panthera tigris corbetti, in a secondary forest in Peninsular Malaysia. The Raffles Bulletin of Zoology, 51, 421-427.

Morrison, M.L., Block, W.M., Dale Strickland, M., Collier, B.A. \& Peterson, M.J. (2008) Wildife Study Design. 2nd ed. Springer, New York, USA.

Noss, A., Kelly, M., Camblos, H. \& Rumiz, D. (2004) Pumas y jaguares simpátricos: datos de Trampas-Cámara en Bolivia y Belize. MEMORIAS: Manejo de Fauna silvestre en Amazonia y Latinoamérica, 4, 229-237.

O'Brien, T.G. (2011) Abundance, density and relative abundance: a conceptual framework. In Camera Traps in Animal Ecology (eds A.F. O’Connell, J.D. Nichols \& K.U. Karanth), pp. 71-95. Springer, New York, USA.

Partanen, P. \& Penttinen, A. (2007) Spatial mark-recapture method in the estimation of crayfish population size. Biometrical Journal, 37, 979-994.

Peña, R., Dosapei, T. \& Cuellar, E. (2004) Densidad y área mínima de acción del jaguar (Panthera onca) en dos épocas del año en Ravelo, Parque Nacional Kaa Iya, Santa Cruz, Bolivia. MEMORIAS: Manejo de Fauna silvestre en Amazonia y Latinoamérica, 4, 257-259.

Pollock, K.H., Nichols, J.D., Brownie, C. \& Hines, J.E. (1990) Statistical inference for capture-recapture experiments. Wildlife Monographs, 107, 97.

Rabinowitz, A. \& Zeller, K. (2010) A range-wide model of landscape connectivity and conservation for the jaguar, Panthera onca. Biological Conservation, 143, 939-945.

Rosas-Rosas, O.C., Bender, L.C. \& Valdez, R. (2008) Jaguar and puma predation on calves in north-eastern Sonora, Mexico. Rangeland Ecology and Management, 61, 554-560.

Salom-Pérez, R., Carrillo, E., Sáenz, J.C. \& Mora, J.M. (2007) Critical condition of the jaguar Panthera onca population in Corcovado National Park, Costa Rica. Oryx, 41, 51-56.

Sanderson, E.W., Redford, K.H., Kitchenette, C.B., Medellin, R.A., Rabinowitz, A.R., Robinson, J.G. et al. (2002)
Planning to save a species: the jaguar as a model. Conservation Biology, 16, 58-72.

Seymour, K.L. (1989) Panthera onca. Mammalian Species, 340, 1-9. Silveira, L., Jácomo, T.A., Astete, S., Sollmann, R., Tórres, N., Furtado, M.M. et al. (2009) Density of the near threatened jaguar Panthera onca in the caatinga of north-eastern Brazil. Oryx, 44, 104-109.

Silver, S. (2004) Estimando la abundancia de jaguares mediante trampas-cámara. Programa para la conservación del jaguar. Wildlife Conservation Society Report for Panthera. Univeristy of Columbia, New York, USA.

Silver, S., Ostro, L. \& Marsh, L. (2004) The use of camera traps for estimating jaguar Panthera onca abundance and density using capture/recapture analysis. Oryx, 38, 148-154.

Stanley, T.R. \& Richards, J.D. (1999) CloseTest. A Program for Testing Capture-Recapture Data for Closure, v. 3. US Geological Survey, Fort Collins, USA.

Wallace, R., Gomez, H., Ayala, G. \& Espinoza, F. (2003) Camera trapping for jaguar (Panthera onca) in the Tuichi Valley, Bolivia. Mastozoología Neotropical, 10, 133-139.

YASUDA, M. (2004) Monitoring diversity and abundance of mammals with camera traps: a case study on Mount Tsukuba, central Japan. Mammal Study, 29, 37-46.

\section{Biographical sketches}

Carmina E. Gutiérrez-González works on the conservation biology of carnivores using a combination of landscape ecology, geographical information systems and field work. She has also been involved in projects on rodents and carnivore communities. MIGUEL A. Gómez-Ramírez has been involved in projects on rodents, bears and jaguars, as well as faunal inventories and studies of mammal communities. Carlos A. López-González focuses on carnivore ecology. His main interests are predator-prey interactions, vertebrate community ecology and the behaviour and conservation of large mammalian carnivores, with an emphasis on the Mexico-US borderlands. 